\title{
Long-Term Trends in Population Size and Breeding Success in the Egyptian Vulture (Neophron percnopterus) in Northern Spain
}

Author(s): Ainara Cortés-Avizanda, Olga Ceballos, JoséA. Donázar

Source: Journal of Raptor Research, 43(1):43-49. 2009.

Published By: The Raptor Research Foundation

DOI: $10.3356 / J R R-08-24.1$

URL: http://www.bioone.org/doi/full/10.3356/JRR-08-24.1

BioOne (www.bioone.org) is an electronic aggregator of bioscience research content, and the online home to over 160 journals and books published by not-for-profit societies, associations, museums, institutions, and presses.

Your use of this PDF, the BioOne Web site, and all posted and associated content indicates your acceptance of BioOne's Terms of Use, available at www.bioone.org/page/terms_of_use.

Usage of BioOne content is strictly limited to personal, educational, and non-commercial use. Commercial inquiries or rights and permissions requests should be directed to the individual publisher as copyright holder. 


\title{
LONG-TERM TRENDS IN POPULATION SIZE AND BREEDING SUCCESS IN THE EGYPTIAN VULTURE (NEOPHRON PERCNOPTERUS) IN NORTHERN SPAIN
}

\author{
AINARA CORTÉS-AviZANDA ${ }^{1}$ \\ Department of Conservation Biology, Estación Biológica de Doñana, C.S.I.C., \\ Avda $M^{a}$ Luisa s/n 41013, Sevilla, Spain \\ Olga Ceballos \\ Equipo de Seguimiento de Procesos Naturales, Estación Biológica de Doñana, C.S.I.C., \\ Avda $M^{a}$ Luisa s/n 41013, Sevilla, Spain
}

José A. Donázar

Department of Conservation Biology, Estación Biológica de Doñana, C.S.I.C., Avda Ma Luisa s/n 41013, Sevilla, Spain

\begin{abstract}
The Egyptian Vulture (Neophron percnopterus) is considered a globally endangered avian scavenger. In the 1980s, Bardenas Reales Natural Park in northern Spain held the densest populations in Europe. There, the population of the wild rabbit (Oryctolagus cuniculus), the main prey of this vulture, decreased dramatically after the arrival of the rabbit hemorrhagic disease (RHD) in 1989, and did not recover. We monitored the population of Egyptian Vultures in Bardenas Reales from 1989-2007. During the study period, the number of breeding territories decreased from 56 to $26(-54 \%)$. In contrast, the percentage of occupying pairs that laid eggs, the number of fledglings per pair, and the number of fledglings per successful nest remained stable, suggesting that the population decline was not attributable to reduced productivity. However, we found 34 dead birds, most of them poisoned, particularly in the second half of the study period (in 1996-1997 and 2004-2007), suggesting that high mortality rates could be contributing to the decline of this species. The fact that poisoning events mainly occurred outside the park suggested that the reduction in numbers of wild rabbits in Bardenas Reales Natural Park forced Egyptian Vultures to move into areas with greater human populations and higher mortality risks. We recommend implementing management measures and environmental education programs to prevent the illegal use of poisoned baits in the area surrounding the park.
\end{abstract}

KeY WoRds: Egyptian Vulture; Neophron percnopterus; Bardenas Reales Natural Park; mortality; poisoning; population trend; reproductive rate; Spain.

TENDENCIAS A LARGO PLAZO (1989-2007) EN EL TAMAÑO DE LA POBLACIÓN Y EXITO REPRODUCTIVO DE NEOPHRON PERCNOPTERUS EN EL PARQUE NATURAL DE BARDENAS REALES EN EL NORTE DE ESPAÑA

Resumen.-El buitre Neophron percnopterus está considerado en peligro de extinción a nivel mundial. En la década de los 80, el Parque Natural de Bardenas Reales, en el norte de España, llegó a albergar la población más densa de Europa. Allí, la población del conejo silvestre (Oryctolagus cuniculus), la principal presa de este buitre, disminuyó drásticamente después de la llegada de la enfermedad hemorrágica del conejo (RHD) en 1989, y no se recuperó. Controlamos la población de N. percnopterus en Bardenas Reales desde 1989 hasta 2007. Durante el período de estudio, el número de territorios de cría se redujo de 56 a $26(-54 \%)$. Además, el porcentaje de parejas con puesta, el número de pollos volantones por pareja y el número de polluelos volantones por nido con éxito se mantuvo estable, lo que sugiere que la disminución de la población no es atribuible a una reducción de la productividad. Sin embargo, hemos encontrado 34 aves muertas, la mayoría envenenadas, en particular en la segunda mitad del período de estudio (en 1996-1997

1 Email address: ainara@ebd.csic.es 
y 2004-2007), lo que sugiere que las altas tasas de mortalidad podrían estar contribuyendo a la disminución de esta especie. El hecho de que los eventos de envenenamiento se produjeran principalmente fuera del parque sugiere que la reducción en el número de conejos silvestres en el Parque Natural Bardenas Reales obliga a estos buitres a salir a zonas con mayor grado de humanización y con mayores riesgos de mortalidad. Se recomienda la aplicación de medidas de gestión y programas de educación ambiental para prevenir el uso ilegal de cebos envenenados en la zona que rodea el parque.

[Traducción de los autores editada]

The European population of Egyptian Vultures (Neophron percnopterus) has decreased in recent decades and the species is considered globally endangered (BirdLife International 2007). Recent censuses have highlighted the continuous decline of the species in Portugal, Italy, and Greece (Tucker and Heath 1994, Cortone and Mordente 1997, Del Moral and Martí 2000). Spain, with ca. 1300 breeding pairs, supports the largest Egyptian Vulture population in the western Palearctic, 37\% of the total European population (BirdLife International 2007). However, it has been estimated that approximately $25 \%$ of breeding pairs in Spain disappeared between 1987 and 2000, despite small local increases in numbers (García-Ripollés and López-López 2006). Consequently, the Egyptian Vulture has been classified as endangered in Spain and is the subject of special conservation concern (see review in Donázar 2004).

The Bardenas (northern Spain) probably held the densest population of Egyptian Vultures in Europe. Densities in this area once reached approximately one breeding territory per $10 \mathrm{~km}^{2}$, with local concentrations of up to seven territories per $1 \mathrm{~km}^{2}$ (Donázar and Fernández 1981, A. Cortés-Avizanda, O. Ceballos, and J.A. Donázar unpubl. data). Here, we describe the trends in the Egyptian Vulture population in the area over the last two decades (1989-2007) and discuss the role of illegal poisoning and other limiting factors in the observed population decline.

\section{STUdy AREA}

The Bardenas Reales de Navarre and Aragón (northern Spain; Fig. 1) cover about 50000 ha and are characterized by a relatively flat landscape dominated by broad plains and mesas. Two differing zones are identified: the 'Bardena Blanca' in the north, a flat area of $450 \mathrm{~km}^{2}$ dominated by cereal cultivation and natural steppes, and the 'Bardena Negra,' in the south, covered by Mediterranean scrubland and pine (Pinus halepensis) forests. Large numbers of domestic animals (up to 90000 sheep) graze in autumn, winter, and spring, and transhumance is practiced. The European rabbit (Oryctolagus cuniculus) was once the main prey item of the predator communities of the Bardenas, primarily in the steppe area (Bardena Blanca). However, with the arrival of the rabbit hemorrhagic disease (RHD) in 1989 (Villafuerte 1995), rabbit populations decreased dramatically and remain at $<10 \%$ of their former levels (Ceballos et al. 1989; Virgós et al. 2007) The wildest part of the area was declared a Natural Park and then Biosphere Reserve in 1999 and 2000, respectively. However, tourism pressure is increasing and ca. 30000 people visit the area annually, with most visitors concentrated in the Bardena Blanca. In the central area of "La Blanca" there is a military base of the Spanish air forces, and training maneuvers there occasionally (once per year) include live ammunition.

\section{MeTHODS}

We monitored the Egyptian Vulture population in the Bardenas Reales continuously from 1989 to 2007. Every year, we surveyed all known breeding territories, as well as all cliffs with potentially suitable nesting sites, primarily during March-April, in order to detect occupied territories. We defined occupied territories as those with adult birds involved in breeding tasks. During April-May, we observed whether adults were incubating, and then, during July-August, we recorded the number of fledglings before nest abandonment. Observations were typically made from vehicles, using binoculars $(10 \times 40)$ and telescopes $(20-60 \times)$, to avoid interfering with the activity of birds. Because in some cases not all the occupied territories were monitored, we made some estimations of breeding parameters based on the number of monitored pairs. Following Bergier and Cheylan (1980), we used three parameters to describe breeding success of monitored pairs: (a) the percentage of pairs that laid eggs [i.e., number of incubating pairs/ number of occupying pairs $(\times 100)]$; (b) productivity: number of fledglings/number of occupying pairs; and (c) fledgling rate: number of fledglings/ number of pairs with fledglings (successful pairs). Mortality events were recorded opportunistically during the regular monitoring of the breeding population. Further data was provided by gamekeepers 


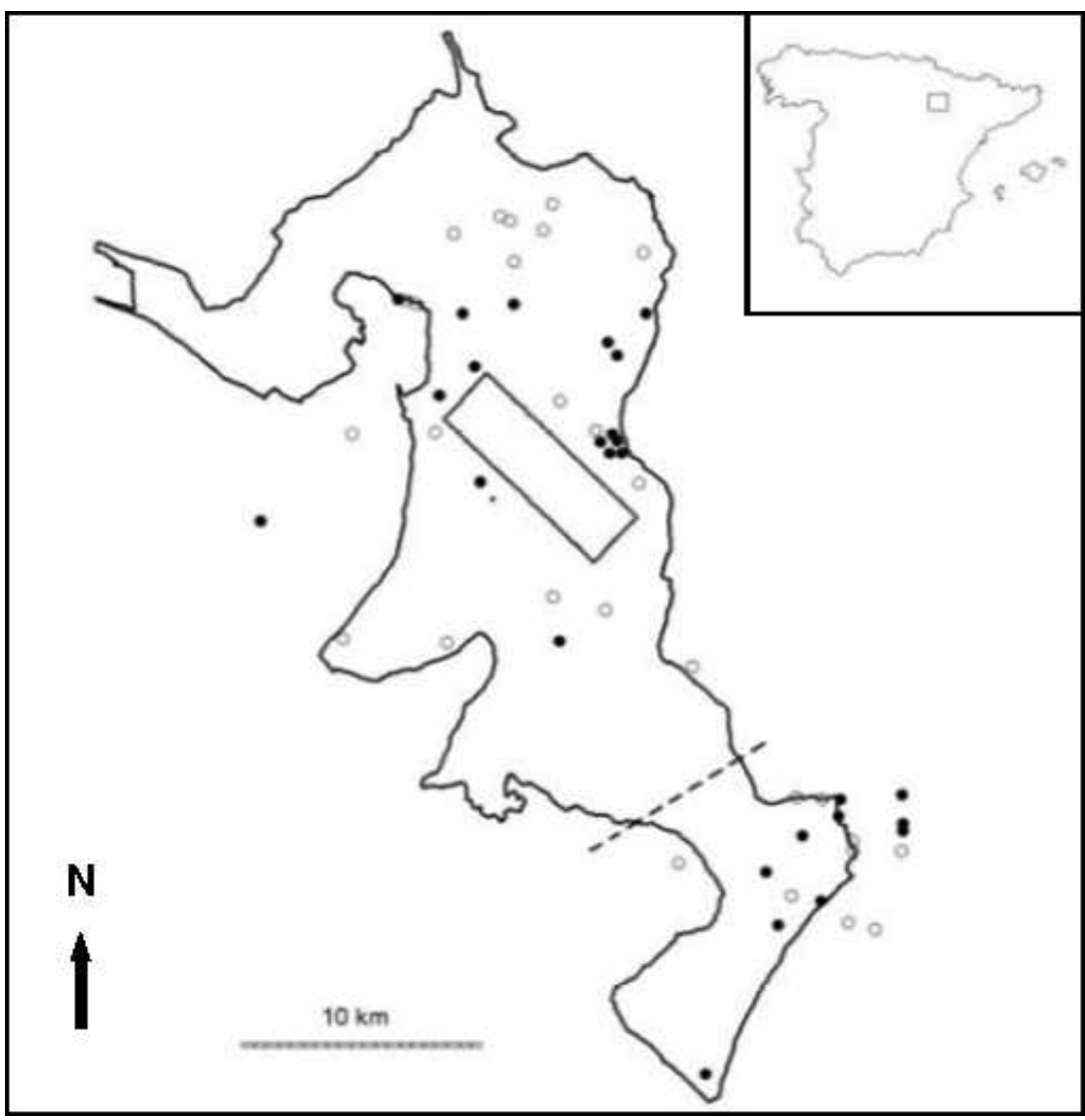

Figure 1. Active Egyptian Vulture territories in 2007 (black circles) and territories abandoned since 1989 (white circles) in the Bardenas Reales in Navarre and Aragón and surrounding areas. The boundaries of the Bardenas Reales Natural Park (Navarre) are shown. The broken line shows the limit between the Bardena Blanca (North) and Bardena Negra (South). The rectangle delimits the military area (included in La Blanca).

working for the governments of Navarre and Aragon. When the remains of dead Egyptian Vultures were fresh enough, the presence of poisons was determined through standard analytical procedures (Hernández and Margalida 2008).

We compared the breeding rates (percent of incubating pairs, productivity, and fledgling rate) of Egyptian Vultures in the Bardenas Blanca and Bardenas Negra using Wilcoxon signed rank tests to test annual values for the two areas (Siegel and Castellan 1988). We used Kruskal-Wallis tests to evaluate trends in three time intervals: before 1995, 1996-2001, and 2002-2007.

\section{Results}

During the study period (1989-2007), a total of 56 individual breeding territories were occupied.
However, by 2007, only 26 territories were still occupied ( $-54 \%$; Fig. 1). The decline became more apparent after 1995 (Fig. 2), and was more pronounced in the Bardena Blanca than in the Bardena Negra $(-48 \%$ and $-37 \%$ of the territories existing in 1989, respectively). Between 1997 and 2007, three new breeding territories were detected, although the pairs occupying these territories ultimately disappeared. The percentage of occupying pairs that laid eggs, the number of fledglings per occupying pair, and the number of fledglings per successful nest all fluctuated greatly and showed no clear long-term trends (Kruskal-Wallis test; $P>$ 0.05; Fig. 3). Despite similar percentage of incubating pairs between the two areas of the Bardenas (Wilcoxon test; $Z=-1.42, P=0.156$ ), the productivity (number of fledglings per occupying pair) and 


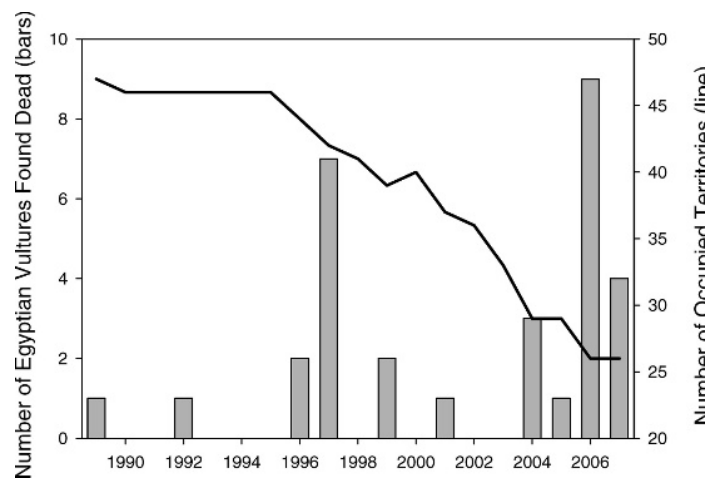

Figure 2. Number of Egyptian Vultures found dead in the Bardenas Reales and surrounding areas (bars), and total number of occupied breeding territories in the study area (line).

the fledgling rate (number of fledglings per successful nest) were higher in the southern part of the region (Bardena Negra; Wilcoxon: $Z=-3.04, P$ $=0.002$ and $Z=1.48, P=0.048$, respectively).

During the study period, 34 Egyptian Vultures were found dead in the Natural Park and the surrounding area $(<20 \mathrm{~km}$ from the park), mostly (94\%) after 1995 (Fig. 2). The highest mortality rates occurred in 1996-1997, and between 2004 and 2007, with 17 birds (50\%) found in 20042007. Most of the dead birds (62\%) were found in breeding territories, usually in or near the nest and, other than two dead chicks, all dead birds found in breeding territories were breeding adults. The remaining dead vultures were found at communal roost sites (two immature birds), a rubbish dump (one immature bird) and in the intensively cultivated areas near the park boundaries (four adult and six immature birds). In two of the above-mentioned cases (the two breeding birds and one immature found at a communal roost) the presence of organophosphates (carbamates, aldicarb) was detected. Moreover, the locations and circumstances of the other dead birds suggest that poisoning was also the cause of most other deaths. For example, three pairs of adults were found dead in their nests (two pairs were accompanied by a dead chick and the other had fresh eggs). Another adult was found dead in an area of irrigated cultivation near the park along with carcasses of a Red Kite (Milvus milvus), a Western Marsh-Harrier (Circus aeruginosus) and a red fox (Vulpes vulpes). Another nine Egyptian Vultures and five Griffon Vultures (Gyps fulvus)
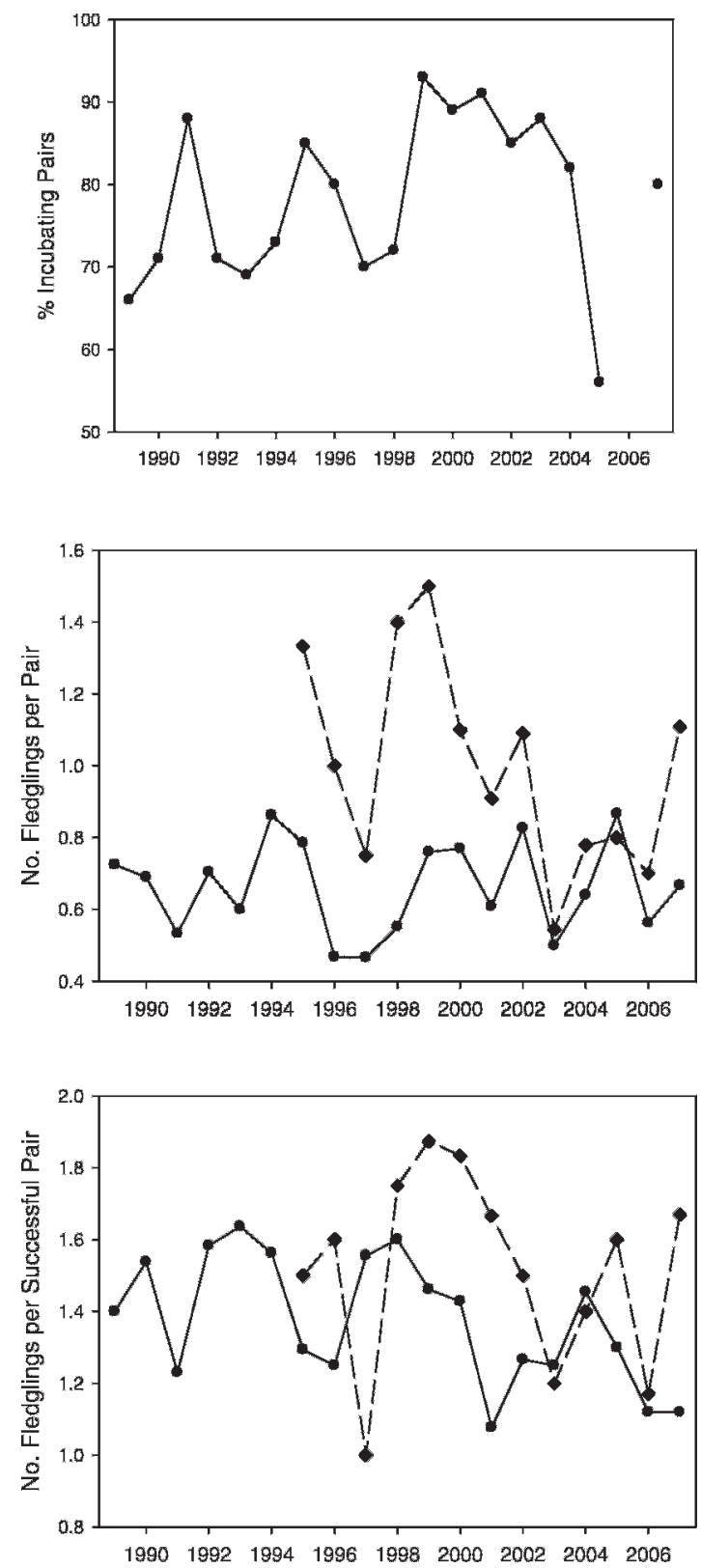

Figure 3. Interannual variation in the breeding success of the Egyptian Vulture in the Bardenas Reales in Navarre and Aragón and surrounding areas, both estimated based on the corresponding number of monitored pairs. Solid line: Bardena Blanca; Broken line: Bardena Negra. Note that we lack data on \% of incubating pairs for 2006 .

were found dead near a pig farm; the analysis of the remains of these birds revealed the presence of carbamates (aldicarb; Diputación General de Aragón pers. comm.). 


\section{Discussion}

Our study indicated that a portion of one of the largest European populations of Egyptian Vultures clearly declined since 1989. A similar decrease has been observed in other parts of the Ebro Valley (70\%; Grande 2006), where the decrease might be ascribed to the combined effects of low productivity, high mortality, and factors operating in wintering areas. Breeding success in our study area, however, showed no clear decrease. Overall, the average productivity of the Egyptian Vulture in our study area, especially in the northern steppe region (Bardena Blanca; 0.6 fledglings per pair) was lower than that in other regions of the Iberian Peninsula and Europe, where it varies between 0.8 and 1.1 fledglings per pair (Donázar et al. 2002, García- Ripollés and López-López 2006 and references therein). It seemed unlikely that low breeding success was influenced by aircraft maneuvers in the central part of La Blanca. Although more specific studies would be required, our own observations revealed that incubating and brooding birds do not show abnormal behavior during these episodes. The relatively poor productivity is likely partially attributable to low food availability. The diet of breeding pairs from the Bardena Blanca formerly consisted of $50 \%$ wild rabbits (Donázar and Ceballos 1988). However, with the arrival of RHD at the end of the 1980s, rabbits ceased to be the primary prey item for the Egyptian Vultures and the percentage of rabbits in the species' prey dropped to $<10 \%$ in 2004-2007 (A. Cortés-Avizanda, O. Ceballos, and

J.A. Donázar unpubl. data). Conversely, in the territories in the southern part of the area (Bardena Negra) Egyptian Vultures depended on waste from pig farms in the 1980s (A. Cortés-Avizanda, O. Ceballos, and J.A. Donázar unpubl. data).

It is likely that the decline in Egyptian Vulture numbers may be attributed, at least in part, to high mortality rates. During the study, we found 34 dead birds, many of which had apparently been poisoned. It is likely that the actual number of deaths by poisoning was much greater than the number of cases we were able to detect, and thus, in our study area, as in other parts of the Iberian Peninsula, poison may be the primary cause of death (Donázar 2004, WWF/ADENA 2006). Such poisons include agricultural compounds such as organophosphates, but may also include veterinary drugs, especially in the area where vultures feed upon intensively reared stabled livestock carrion (Blanco et al. 2007, Lemus et al. 2008).
Recent research with Cinereous Vultures (Aegypius monachus) and Bearded Vultures (Gypaetus barbatus) indicated that mortality rates for these species also were high (Hernández and Margalida 2008, Margalida et al. 2008). Studies of the population of the Ebro Valley (including Bardenas) using capture-recapture techniques showed that the annual survival rate in adults (0.75) is unexpectedly low for a bird as long-lived as the Egyptian Vulture (Grande 2006), and also revealed that the study area and in general the whole Ebro Valley acts as a sink, given that it attracts individuals from neighboring populations (Grande 2006).

The vulnerability of the Egyptian Vulture population in the Bardenas to poisoning may be enhanced by the previously cited decrease in the wild rabbit population. After the disappearance of their main prey item, Egyptian Vultures were likely forced to search surrounding areas dominated by irrigated crops and game preserves, where the possibility of finding poisoned bait was much greater. The illegal use of poisoned baits to kill predators has become much more prevalent in this region since the 1990s (Villafuerte et al. 1998). Hunters believe that the disappearance of the rabbit may be associated with the high numbers of carnivores, particularly red fox, (Villafuerte et al. 1998, Virgós et al. 2007). Studies of other species such as the Red Kite have revealed that avian scavenger populations have decreased most precipitously in areas of Spain where there are small-game rabbit preserves (Villafuerte et al. 1998). This phenomenon is occurring throughout Spain, and between 1990 and 2007, 294 Egyptian Vultures were found to have been killed by poison in the country (M. Hernández and A. Margalida unpubl. data). In addition, in recent years Griffon Vultures have also been deliberately poisoned, as some livestock farmers believe that, with the closure of some of the supplementary feeding stations (the so-called 'vulture restaurants'), vultures will begin to attack cattle (A. Margalida and D. Campión unpubl. data).

Based on our results, we conclude that the most efficacious way to reverse the negative trend of the Egyptian Vulture population in the Bardenas is to increase survival rates. One of the most important issues that must be addressed is the proper management of the area surrounding the Bardenas. As has been described for other large vertebrates, despite the strict conservation measures inside the park's protected areas, species that use large ranges may cross park boundaries and move into areas with greater 
human populations and there they are still exposed to high risks of mortality (Sergio et al. 2005, Groom et al. 2006). We recommend conservation efforts should focus on public education and the oversight of game preserves and livestock operations, where the use of poison is thought to be commonplace.

In the near future, the Egyptian Vulture population of our study area may also be influenced by other factors. The number of wind farms is increasing rapidly in the area surrounding the Bardenas Reales Natural Park and, because of collision incidents in Navarre and other important areas for the species such as Cádiz (Barrios and Rodríguez 2004, Donázar and Benítez 2004, Lekuona and Ursúa 2007, Navarre government unpubl. data), it is thought that the species has a high risk of collision. Moreover, human disturbance (primarily tourism), which has increased significantly in the park, may compromise the breeding success of pairs, especially if numbers of visitors continue to grow.

\section{ACKNOWLEDGMENTS}

Financial assistance was provided by Governments of Aragón and Navarre (Jesús Antonio Insausti, Javier Forcada and Jokin Larumbe), Viveros y Repoblaciones de Navarra, S.A. (David Campión) and the project CGL200400270. We are especially grateful to Alejandro Urmeneta, José Antonio Pérez Nievas, Carmelo Fernández, Paz Azkona, Carlos Astrain, Alfonso Senosiain, David Campión, Manuel de la Riva, Juan Manuel Grande, and Esperanza Ursúa, whose help and enthusiasm made the long-term monitoring of the region's Egyptian Vulture population possible. Antoni Margalida, Fabio Liberatori, Guillermo Blanco, and Roger Jovani kindly reviewed an earlier version of the manuscript.

\section{Literature Cited}

BARrios, L. AND A. Rodríguez. 2004. Behavioural and environmental correlates of soaring-bird mortality at onshore wind turbines. J. Appl. Ecol. 41:72-81.

Bergier, P. and G. Cheylan. 1980. Status, succès de reproduction et alimentation du vautour percnoptère $\mathrm{Neo}$ phron percnopterus en France méditerranéenne. Alauda 48:75-97.

BirdLife InTERnAtional. 2007. Species factsheet: Neophron percnopterus. http://www.birdlife.org (last accessed 26 February 2008).

Blanco, G., J.A. Lemus, J. Grande, L. Gangoso, J.M. Grande, J.A. Donázar, B. Arroyo, O. Frías, and F. HirALDO. 2007. Geographical variation in cloacal microflora and bacterial antibiotic resistance in a threatened avian scavenger in relation to diet and livestock farming practices. Environ. Microbiol. 9:1738-1749.

Ceballos, O., J.A. Donázar, and C. Fernández. 1989. Estudio de la repercusión de la Parvovirosis del conejo de campo (Oryctolagus cuniculus) en las poblaciones de grandes rapaces (Bubo bubo, Neophron percnopterus, Aquila chrysaëtos y Hieraaetus fasciatus) en Navarra. Servicio Medio Ambiente, Gobierno de Navarra, Pamplona, Spain.

Cortone, P. And F. Mordente. 1997. Osservazioni sul comportamento e sulla biología riproduttivi del Capovaccaio, Neophron percnopterus, in Calabria. Riv. Ital. Ornitol. 67:3-12.

Del Moral, J.C. And M. Martí. 2000. El Alimoche Común en España y Portugal (I Censo Coordinado). 2000. Monograph No. 8. SEO/BirdLife. Madrid, Spain.

DONÁZAR, J.A. 2004. Alimoche (Neophron percnopterus). Pages 129-131 in A. Madroño, C. González, and J.C. Atienza [EDS.], Libro Rojo de las Aves de España. SEO/BirdLife and Ministerio de Medio Ambiente, Madrid, Spain.

AND J.R. BENítez. 2004. La industria eólica, otra amenaza para el alimoche en el sur de Cádiz. Quercus 226:68-69.

And O. Ceballos. 1988. Alimentación y tasas reproductoras del Alimoche (Neophron percnopterus) en $\mathrm{Na}$ varra. Ardeola 35:3-14.

And C. Fernández. 1981. Censo de cinco rapaces rupícolas en Navarra: Quebrantahuesos, Águila real, Águila perdicera, Halcón común y Alimoche. Rev. Príncipe de Viana, (Suplemento de Ciencias) 2:435-441.

, C.J. Palacios, L. Gangoso, O. Ceballos, M.J. GonZÁlez, AND F. Hiraldo. 2002. Conservation status and limiting factors in the endangered population of Egyptian Vulture (Neophron percnopterus) in the Canary Islands. Biol. Conserv. 107:89-97.

García-Ripollés, C. ANd P. LóPEz-López 2006. Population size and breeding performance of Egyptian Vultures (Neophron percnopterus) in the eastern Iberian peninsula. J. Raptor Res. 40:217-221.

GRANDE, J.M. 2006. Factores limitantes antrópicos y naturales de poblaciones de aves carroñeras: el caso del Alimoche (Neophron percnopterus) en el valle del Ebro. Ph.D. dissertation, Universidad de Sevilla, Sevilla, Spain.

Groom, M.J., G.K. MefFe, and C.R. Carroll. 2006. Principles of conservation biology, Third Ed. Sinauer Associates, Sunderland, MA U.S.A.

Hernández, M. And A. Margalida. 2008. Pesticide abuse in Europe: effects on the Cinereous Vulture (Aegypius monachus) population in Spain. Ecotoxicology 17:264-272.

LEKUONA, J.M. AND C. URsúA. 2007. Avian mortality in wind power plants of Navarra (Northern Spain). Pages 177-192 in M. de Lucas, G.F.E. Janss, and M. Ferrer [EDS.], 2007. Birds and wind farms: risk assessment and mitigation. Quercus, Madrid, Spain.

Lemus, J.A., G. Blanco, J. Grande, B. Arroyo, M. GarcíaMontijano, and F. Martínez. 2008. Antibiotics threaten wildlife: circulating quinolone residues and disease in avian scavengers. PLOS ONE 3:e1444.

Margalida, A., R. Heredia, M. Razin, and M. Hernández. 2008. Sources of variation in mortality of the Bearded Vulture (Gypaetus barbatus) in Europe. Bird Conserv. Int. 18:1-10. 
Sergio, F., J. Blas, M. Forero, N. Fernández, J.A. DonÁzar, AND F. HiRALdo. 2005. Preservation of wide-ranging top predators by site-protection: Black and Red kites in Doñana National Park. Biol. Conserv. 125:11-21.

Siegel, S. And N.J. Castellan. 1988. Nonparametric statistics for the behavioral sciences, Second Ed. McGrawHill, New York, NY U.S.A.

Tucker, G.M., and M.F. Heath. [Eds.]. 1994. Birds in Europe: their conservation status. BirdLife International, Cambridge, U.K.

Villafuerte, R., C. Calvete, J.C. Blanco, and J. Lucientes. 1995. Incidence of viral haemorrhagic disease in wild rabbit populations in Spain. Mammalia 59:651-659.
J. Viñuela, AND J.C. Blanco. 1998. Extensive predator persecution caused by population crash in a game species: the case of Red Kites and rabbits in Spain. Biol. Conserv. 84:181-188.

Virgós, E., S. Cabezas-Díaz, and J. Lozano. 2007. Is the wild rabbit (Oryctolagus cuniculus) a threatened species in Spain? Sociological constraints in the conservation of species. Biodivers. Conserv. 16:3489-3504.

WWF/AdENA. 2006. El veneno en España (1990-2005) Análisis del problema, incidencia y causas. WWF, Madrid, Spain.

Received 23 April 2008; accepted 13 October 2008 Associate Editor: Vincenzo Penteriani 